International Journal of English Literature and Social Sciences
Vol-6, Issue-4; Jul-Aug, 2021

Peer-Reviewed Journal

\title{
Picking a Thing Apart: A Postmodern Reading of Olga Tokarczhuk's 'Flights' as a constellation Novel
}

\author{
Daniel Rubaraj R
}

Assistant Professor, PG and Research Department of English, The American College, Madurai, Tamil Nadu, India.

Received: 28 Jun 2021; Received in revised form: 20 Jul 2021; Accepted: 03 Aug 2021; Available online: 13 Aug 2021

(C2021 The Author(s). Published by Infogain Publication. This is an open access article under the CC BY license

(https://creativecommons.org/licenses/by/4.0/).

\begin{abstract}
The concept of 'Constellation' which means a group of visible stars forms a perceived pattern, typically representing an inanimate object. "Constellation is not sequencing, it carries truth", in order to Reflect someone's experiencing more accurately, it is necessary instead to gather a whole, out of pieces. The Present Study attempts a postmodern reading of Olga Tokarczuk's 'Flights' as a 'constellation' novel in which bunch of seemingly separate stories, experience and historical artifacts combine into a growing peak of emotional, physical and political interconnectedness. Although the novel is considered a postmodern invention, Olga Tokarczuk presents a unique pattern or style to her novel. 'Flights' is ultimately a novel about picking a thing apart. The author has a talent for pushing us inward, into ourselves, our bodies and also our tormenting histories so that we can remerge knowing all of our collective parts
\end{abstract}

Keywords - Constellation, interconnectedness, inward pushing, tormenting histories, postmodernism.

The novel Flights brings out the various historical events, mythology of human life and death through different narrative sections like migration. This research paper focuses on the fabulous narrative method of the author bring out through the nameless narrator who carries the entire story till the end without getting us back. In the whole 116 fragmentary narrations, first of all the book starts with the narrators biography "Here I am", a few year old child left alone in the house surrounded by toys and dolls. The house filled with darkness and silence where the small girl can hear her parents' voice and footsteps. There she experience some kind of isolation because every one left her alone, later she realize that her own presence is the only thing with different outline now and there is nothing any one can do. The first deconstruction that takes place in the novel is the concept of travel. The narrator gives some brief comparison about the lifetime travelers and the common people who travel for nothing. She complains about her parents that "they weren't real travelers; they left in order to return" [12]. Tokarczuk travels wherever she wants to; whenever she travels no one knows where she is. At any Airport, there should be lots of people like her because immigration officially starts begin there when people stamp their passports. That's why fluid, movement and illusions these are precisely what makes us civilized. With little amount of money she set off her first trip and took odd job wherever she happened to be. Again she travels whenever she gets some money. She basically a psychology student, Somehow we can found psychological facts in this novel. After completing her degree in Psychology, she doesn't exercise the trade which she trained for long. Then she started writing a novel meant for travelers. The chronicles of her travels can actually be the chronicles of an illness. She suffers from a syndrome that is easily found in any atlas of clinical syndrome, at least according to literature scaling a higher and higher frequency. According to the old edition of The Clinical Syndrome (published in the seventies), which is an encyclopedia of a kind of syndrome. For her, it was an endless inspiration (flights 21). Here the idea of the syndrome applies to travel psychology like a glove. A syndrome is small not weighed down by theory or episodic that we can explain something with it and then reject it, a disposable tool of 
knowledge.

The novel 'Flights' is a picture of journeys, which are the results of a collection of curiosities. The narrator identifies the pillars of his knowledge as "physiology and theology", the body and soul. An unpredictable rat, an armored chair with fountains, explores the realities hidden inside the novel and is discovered only by pilgrims to find these exceptions that refuse to be backed up by explanation. Though some observation on travelling, the real pleasures of "Flights" lies in the stories and tales that she intersect throughout. Acting with envious optimism, Tokarczuk moved from an art museum to a casual conversation with fellow travelers to explain the social invisibility of middle-aged women effortlessly within four pages, the story of a man named Kunicki whose child and wife disappeared on vacation. The search for his missing family is first enduring story, which was interrupted in the middle but briefly revisited after three hundred pages. In the middle ages, there are ten other stories of amputated, in which a $17^{\text {th }}$-century anatomist separates his leg; A woman was summoned to Poland by mysterious emails to see her first love; and a woman who leaves her family to live as a travel beggar. Readers looking for these stories to come to a clean conclusion may be disappointed. Tokarczuk was not much interested in building loose edges or explaining how the pieces fit. Each story appears, grabs our attention and then fades as we tell the story of new hotel and airport.

When Tokarczuk later returns to Kunicki's story in the book, the family is back together in Poland, aliens. Kunicki is skeptical of every move his wife and child make, following them about their daily lives when he has to work, making sure something is wrong. Every time he confronts them about what happened, both will be fired at his trial. His wife says he ate freshly caught fish from the sea and took refuge in a hut for three days. After they came back. Nothing more or less.

In another story, a Muscovite woman abandons her unhealthy home life with a chronically ill child, a careless husband, and a mother-in-law - not to go packing around the world as you suspect, but to ride the city's extensive subway system permanently. Tokarczuk effectively controls the reader's temptation to judge this woman by allowing us the comforts she receives from this strange new life. With no place to go she rides on long trains, she begins to recognize more loving spirits, and she becomes more and more aware of how citizens travel. She starts to smell, runs out of money, but can't explain why she's not really homeless; people buy her food and subway tickets. Before she can feel neglected, she feels pity and unnoticed. Her life changes as Tokarczuk listens to you and others see their own things, is that the journey? Balancing questions like these on the edge of the knife, Tokarczuk maintains a sharp pace by attacking and comforting the reader simultaneously throughout the more than 100 stories in this 400-odd page book; it also makes us feel alone in an area that is bigger than we think.

The story focuses specifically on how naming things changes their character. Many stories, especially about a frustrated sailor reclaiming his old name, explore the ideas that we can change what things are by discovering all. She writes:

"The description is synonymous with overuse destroys; the colors fade, the corners lose their definition and eventually the ones described begin to fade and disappear...The truth is terrible: Describing is destroying."(Flights, 75)

One of the book's most instructive micro-articles is about Wikipedia, which Tokarczuk rightly praises as a wonder of the world, a project that gathers knowledge from around the world. She changes course in the second column of her riff. The problem with Wikipedia is that it can only contain what we can represent in words.

We should have some other collection of knowledge, then to balance that one out-its inverse, its inner lining, everything we don't know, all the things that can't be captured in any index, can't be handled by any search engine. For the vastness of these contents cannot be traversed from word to word...Matter and anti-matter. Information and anti-information. (Flights 78, 79)

In traditional novels such as traditional psychology (e.g. Jungian), the authors consider people to be stable and balanced. On the other hand flights are full of people "in traffic" and "moving from place to place". As one women who gave a speech at an airport argued, "If we want to list humanity in a certain way, we can only do so by stopping people in a certain movement and moving them from place to place. Her co-lecturer added, "One cannot from a fixed cause and effect cause and effect argument or create an explanation with events that succeed and follow each other without cause." To do so, she says, it's only an approximation of life. After some time the first person narrator stops listening the lecture and started complaining that the speech was too long.

We don't have to do anything - we have to show up, sign in only one frame of time and place. We will find our great love and happiness there....

Many people believe that there exists in the world's coordinate system a perfect point where time and space reach an agreement. This may even be why these 
people travel; leaving their homes behind, hoping that even by moving around in a chaotic fashion they will increase their likelihood of happening upon this point. Landing at the right time in the right place - seizing the opportunity, grabbing the moment and not letting go... (Flights, 85).

Tokarczuk combines "the right time and place" with the themes of wandering, fragmentation, exploration and travel. Therefore the novel flights are fragmented into important pieces of modern life, cultivating the importance of wandering, travel and time. Tokarczuk's writing shifts seamlessly from mythology to realistic accounts of place and objects, subtle depictions of human activities and motives, and the great purpose of Eastern European history and the role of faiths.

In One of Tokarczuk's travel diaries, she had an experience with a strange lady who stayed in hotel with her. Aleksandra was her name - leaned on the croissants and said:

'The true God is an animal. He's in animals, so close that we don't notice. Every day God sacrifices him for us, dying over and over, feeding us with his body, clothing us in his skin, allowing us to test our medicines on him so that we might live longer and better. Thus does he show his affection, bestow on us his friendship and love' (flights, 73).

Travels are absolutely necessary to this novel. The novel flights contain a reproduction of eleven maps, including the wandering of Odysseus on flights. Tokarczuk often associates travel with books. For example, the title of her first novel 'The Journey of the Book People', the word of Journey also occurs in the subtitle called 'The Books of Jacob'. She criticizes some travel guide books because they "have weak points and obscure their definitions" (flights, 69). Nevertheless, Tokarczuk commented, "In her own journey she has been faithful to two books because they were written with genuine interest and a genuine desire to portray the world" (flights, 70).

'Life for someone like Erik is made of inevitable highs and lows, similar to the rhythmic rocking of the waves and the sea's inexplicable ebbs and flows' (flights, 101).

Here, the Stories don't have to be straight forward; flights are definitely not - like there is no life. Author Marlon James works on this book "acting like a dream: with fragmented clues that add to the novel's happy redesign. In one piece, Erik - a character who travels a lot travels ten years to get home. When he thinks he's going home, "suddenly some new opportunities arise, often not in the right opposite direction", and he concludes that "the real argument is the old one - the earth is round, so stay close to the directions we do not want."

According to travel psychology, island represents earliest primitive state before socialization, even though the ego has already been customized enough to achieve a certain level of self-awareness yet complete without fulfilling its relationships with its surroundings. Island is a state of rearrangement within one's own boundaries that unhindered by any external influence: "One satisfies all one's needs on one's own. Only the self seems real; the other is but a vague specter". In fact this is not an image of one's imagination, nor a vision which adorned with an eye accustomed to a straight line that separates the field of view and above (flights, 103).

Travel and place are another central theme in the author's poems. Tokarczuk's travels are cycles of energy that inevitably attract cosmic stimuli that affect humans. In flights a women named Spin's sister Ludvica travels to bring her brother's heart from Praise to Warsaw; Monk Pasalis travels from his cell to the city of Gladys in a convent in the woods and brings the panic of St. Cummurnis to Rome, where it finally arrives. A women travels from a small town to a big city in search of a boyfriend who wipes out her bad words in her.

Dream and is rewarded by the fate of her imaginary courage. Tokarczuk's novels presented: facts and characters have been alive, reappearing without fear of bothering. Unlike many Polish novels, flights handle travel, which is a global theme. This is not surprising to readers who are not immersed in a hermetic Polish context. Although the stories narrated by Tokarczuk take place in Poland (such as the transfer of Spin's heart from Paris to Warsaw), the Polish system has more background than the main point of the story. Travel is a frequent theme in fiction, from the early Picaresque novels to the modern "road" journey of Jack Kerovak and Hunter S. In the increasingly globalized world, this is more relevant to the theme of travel than ever before, so the book's continental appeal.

In the novel flights, there is also a global theme of protection: these characters dedicate their lives to finding the right chemical compound for many embossed legs and organs, never decomposing. This is the reputation of the Tsar of Russia for capturing and collecting the enviable rare 'specimens' that a scientist tries to take only to the palaces of St. Petersburg to lose at sea. Some of the best details in these stories are horrible and although they are hard to read, they all gave fullness to the novel. Some chapters in the book appear to have 'no consequences', interrupting other chapters without making them a part of it. Some fragments connect to each other and sometimes the link is through a shared theme - 
travel and human anatomy. Alternatively, the link may be in the first language, i.e. when two fragments starts with same first line: "Each of my pilgrimages aims at some other pilgrim" (flights, 129).

Travel gives moments of depression and difficulty to find difference in the discipline of travel psychology, in the novel flights, it is connected by never author herself. She gave simple and elegant details of her journey that never quiet down in this mysterious world. This marvelous starting to be studied the travel psychotheology. Travel shows god in our own:

"Once the gods were external, unavailable, from another world, and their apparent emissaries were angels and demons. But the human ego burst forth and swept the gods up and inside, furnished them a place somewhere between the hippocampus and the brain stem, between the pineal gland and Boca's area. Only in this way can the gods survive - in the dark, quiet nooks of the human body, in the cervices of the brain, in the empty space between the synapses" (flights, 181)

In Belau's travel mostly related to history of Frederic Ruysch, the Dutch anatomist of the late $17^{\text {th }}$ century. Blau inspired lot from human body and had hundreds of photo collections. The bodies are basically similar, there is no more mystery and they are like fingerprints, in fact they can use those uncomfortable elements that the police have not yet appreciated to identify

- They are completely unique. They look beautiful as insect-attracting orchids with their shape and color. What a strange thought - this botanical mechanism is somehow preserved even in the era of human development to say that it was effective would reduce it and seems to him that nature was so pleased with the idea on which this magazine was based, that it was cut to carry it further, that in spite of the fact that man would drown with a soul, then it would hide in the underneath in silence. "Every body parts deserved to be remembered. Every human body deserves to last" (Flights, 134-135). Blau's main motto to discover the famous preservation concoction of the anatomist Ruysch. There was a story describes how the ship carrying Ruysch's sample to Russia for several days. In the ship, the Russian sailors drank some of the fluid that protected the samples, after the vodka left. Even it's true or not the book that mixes truth with fiction, a lot research needed to establish what actually happened. There are more than thirty five pages in the book describes the Museum in St. Petersburg, where he observes anatomical specimens in glass jars.

Renowned scientist, Philip Verheyen was an anatomist and surgeon who combine the theme of anatomy with body parts as religious monuments and as a bizarre story. It focuses on how verheyen's leg was affected and amputated when he was twenty-eight. The journey of the letter to the amputated leg project the entire thought of Philip Verheyen's death and his record of dissected leg. He addresses his leg as a living individual which can hear out whatever he talks. That painful relationship makes a kind of difficult thing that no one can go through. However, it is obvious that we can only believe in physiology and theology which we can considered as a main pillars of facts. Looking his notes, we can find out that Philip Verheyen ceaselessly suffer by pain without identifying the reason. Some of the points that we can't ignore whenever read:

Why am I in pain? Is it because - as that grinders says, and perhaps only in this does he not err - in essence the body and soul are part of something larger and something shared, states of the same substance, like water that can be both liquid and solid? what can do not exists cause me pain? Why do I feel this lack, sense this absence? Are we perhaps condemned to wholeness, and every fragmentation, every quartering, will only be a pretence, will happen on the surface, underneath which, however, the plan remains intact, unalterable?(flights, 218).

Slowly, he had more and more questions that ended with his life and for what he done for his life. Tokarczuk linked those questions of travel in the novel flights. Philip aim to find the rare nerve which we can only find in our leg, of course he did - he counted the tendons and blood vessels but he had a strong believe that something that he not missed:

"I've spent my life travelling, into my own body, into my own amputated limb.... I've used my own eye for this, but relied, too, on the cleverer vision of the microscope. I believe I have not missed even the smallest part. Today I can ask myself this question: what have I been looking for?" (Flights, 219).

Similarly, Tokarczuk bring the story of Josephine Soliman von Feuchtersleben's letter to Francis I, Emperor of Austria, in which she pleads for the release of his father's mummy's body - so that she can be give a Christian burial. Angelo Soliman, who was first brought to Europe as a slave from Africa, was raised in a high society. He was highly educated man, he moved into aristocratic and artistic circles and was a friend of Hayden. After his death, he was mummified and by his daughter words:

Flight symbiotic relationships in nature are portrayed as an advanced model of human uniqueness. One of the protagonists, a biologist, refutes the notion of 
evolution:

"Darwin read this energy as well as he could, but he still read is wrong. Competition. The more experienced a biologist you become, the longer and harder you look at the complex structures and connections in the biosystem, the stronger your hunch that all animate things cooperate in this growth and bursting, supporting one another, permit one another to make use of them. If rivalry exists, it is localized phenomenon, an upsetting of the balance. It is true that tree branches jostle one another out of the way to reach the light, their roots collide in the race to a water source, animals eat each other, but there is in all this a kind of accord, it's just a accord that men find frightening" (flights, 294).

Tokarczuk had a beautiful experience by giving ride to young Serb Nebojsa, he fully talks about the stories of war. But first she regret, later he explains war of death that make some uncomfortable and make some comfortable after a time. Like he said:

'At first you always see what's alive and vibrant. You're delighted by nature, by the smells and all that. But the longer you're in a place, the more the charm of those things fades. You wonder who lived here before you came to this home and this room, whose things these are, who scratched the wall above the bed and what tree the sills were cut from......' (Flights, 314-315).

Tokarczuk wrote the novel between Flights and The Book of Jacob and his commentary is unarmed, including two book deals and a simple fashion for detective stories. Hunting the story has become a hotly debated political issue in Poland since the novel was published, but at the time some said "she was an old mad woman and this big debate started on the internet about what we can do about this patriarchal, Catholic tradition" (Armistead, 2018). One may wonder if there is any trace of his studies and his previous career as a psychoanalyst in the works of Olga Tokarczuk, i.e. whether psychological and psychological analysis contributed to his literary achievement. This question somehow changes the terms of a proposition that has always been known to psychoanalysts from Freud and Jung: writers, artists, who know how to search the secrets of the world better than anyone else, and they know more about the mind than psychoanalysts. Freud often wanted to quote a phrase from Shakespeare's Hamlet, which expresses all doubts about the possibilities of science: Horatio has many more things in heaven and earth than you dreamed of in your philosophy (Hamlet, Law I, Scene V).

Flights novel, there are races and generations who are always wrong, or like the bizarre and unthinkable Van Goetzon in House of Day, House of Night, and
House of Night, they are looking for it. A narcissistic retreat in the most private homes closed to the world, absorbed in

luxurious and profoundly central activities, has almost abandoned itself to pre-existing levels of compliance with higher definitions, participation, and involvement in worldly life. Extraordinary even in death:

The von Goetzen always died beautifully and gently. Death came over them like a mist, like a sudden break in the electricity supply - their eyes grew dim, their breathing slowed down and finally died away. Those attending the deathbed had only to close their departed relative's eyelids and then go about their business - in the warmth of the conservatory, the coolness of the groundfloor corridors, among the rustling pages of illustrated books on horticulture and art [ ]. There were photographs left of the deceased, as well as flowerbeds, diaries, cupboards full of moldering clothing, and crumbs in the bed-sheets, but someone else would immediately occupy his room, so it was as if they had never died. Besides, as a result of all the family intermarrying they were all so alike that the lack of a particular individual was never felt." (Tokarczuk, 1998, p.196).

Tokarczuk discovers talking world by adapting her volcanic imagination and language. Earth is made up of natural facts filled with plants, animals, rocks, weathers etc.., in brief everything exists in this world is live - in deep earth also a living things which give us life and sources. Tokarczuk mention half of the novel about ecology and living nature. We can somehow discover the emotions, movements and breath-that denote the earth still alive. Disruption of the balance of human nature and the unresolved nature of the body-soul relationship speaks to something similar to the voice of contemporary writers.

"Then they learned from the Icelanders that no real ill could have come to them: for lost souls like them the earth is able to bare its warm nipples.You just have to suck at them with gratitude and drink the earth's milk. Apparently it tastes like milk of magnesium - what they sell in pharmacies for hyperacidity and heartburn" (Flights, 370).

Some believe in enlightenment, some not; one Chinese traveler shared his experience in India that we can find out the fear of enlightenment. The Bodhi tree is a scared place in India for him because it is the most important tree under which the Buddha attained enlightenment. An untitled character is lucky enough to visit "the scared place where Buddha enjoyed his enlightenment" under a large fig tree. The Chinese (anonymous) paid homage to this place, worshiped it many times, left large donations but did not experience any 
enlightenment and get disappointed. What he felt was embarrassment and helplessness, which turned into fear. He realized that he was not sure he wanted to experience enlightenment. The novel Flights had lots of mythical allusions of Ancient Greece, when referring to the myths; the author refers to the god of the time - KAIROS. He is the ancient Greek god of happiness who supports opportunities and favorable moments.

The novel FLIGHTS, a wonderful, weird and ultimately disgusting book by 2018, Man Booker International Prize Winner Olga Tokarczuk has made us to consider the importance of forms filled with memorable lines and real image. The very uniqueness projected in the novel is fragmentation - using the metaphor 'Constellation'. The concept of Constellation already discussed in the chapter -1 by using various reviews and through historical and literary content. The Flights - not just the medical part of the story - are very intimate. But there are similarities: similarities of realism and the use of cirrhosis. Rembrandt and Tokarczuk both express the best out of the darkness. Enlightenment is about capturing, understanding and suppressing. In Poland, the story of a fragmented, diverse, and intertwined history is inevitably political, disrupting the country's long-standing myths as a long-standing Catholic nation. This national myth in recent years, especially since 2015 , when the Social Conservative Party came to power in law and justice, anti-immigration has risen on the platform of general strength. Since then, the government has refused to accept refugees from the Middle East and North Africa, opposed the granting of equal rights to same-sex couples, and passed legislation banning discussions about Polish cooperation with the Nazis during World War II. Tokarczuk specially took of these myths as a key point to her writing by including some political affairs - through some notable characters. Basically, Tokarczuk - a feminist, in her novels most of the characters are females that we can understand how she gave importance to women.

The fact that a section of modernists were pioneers almost a century ago has reached its final shape within the pages of aircraft. The book has one hundred and sixteen parts or vignettes, each telling a different story, yet connected by emotions, perceptions and thoughts and stories of the characters. The characters, or "people" as the translator calls them, are the most memorable to the most completely forgettable. Take the woman that everyone wants to be a writer. The sole purpose of a Muslim woman's life is to get all the people of her country to write books and read books to each other. He gathers about seven hundred members in an online community dedicated to his cause. Flights not only tell fragmentary stories, but also make readers question and re-evaluate their own travel philosophies. Even the availability of "travel-sized" items in pharmacies and supermarkets does not detract from Tokarczuk's study, which states that "the cosmetics industry thinks the travel event reflects a sedentary life, but in miniature, a pretty little baby version is the same. "

The format based on the fragments is most apparent for a novel by a Polish writer, where national boundaries have changed over the centuries, and many ethnic groups - Poles, Ukrainians, Lithuanians, Germans, Ruthenians, Jews - side by side in a cocoon of languages and experiences. Central European literature in general, Tokarczuk believes, "makes reality more questionable. It is more distrust of fixed, permanent things.

The topic Flights as a "Constellation novel" explains how Tokarczuk endeavor the metaphor by connecting different experience and historical stories. In contemporary writing, fragmentation plays a vital role but when it compares to Tokarczuk novel, she made a history that everyone should remember. Maximum six to ten parts of fragmentation we come across - but more than hundred stories we can only find in her writing, each and every topic take us to different world, can't ignore any. Through hundred and sixteen fragmentation we can find that the book is a call to reflect on the role of opportunity in our lives, how our lives are not mapped out and what paths we can take and things may change differently if we do. This is a book that needs to be realized — reading it is very experiential, almost full of magic insight. Tokarczuk takes us from one voice to another, changing tones and themes, sometimes creating a rich, poetic climax. For example, when a famous professor of Greek history suffers a stroke, Tokarczuk presents an extraordinary image of all the places he has spent his life, immersed in the never-ending red liquid, connecting his brain-filling blood with Homer's famous "wine" - the Dark Sea. "All of this makes flights an adventurous adventure in the possibilities of non- linear storytelling. Poland's own history of disappearing and reappearing on the map of Europe is told by Tokarczuk, whose literature is fragmented and uncertain. The structure of airplanes also draws Tokarczuk's background in psychology, reflecting the human mind's avoiding one train of thought, jumping to conclusions, and drawing connections based on intuition rather than logic.

Ethnos and mythology, the fairy tale in the background of geography and the political and everyday history of places, despite their uniqueness, connect it with the history of mankind and global ethics. The strangeness we see in her pages is not only the coming past or exploding Repression, but also a shock to the anger of 
fear, routine and selfish hardened and emotions, a new insight into things. It takes the form of an invitation to think about something new and nothing, awareness, a moment of origin and the free circulation of energy in the mental and real universe or the manifestation of events that call into question human existence on earth, renewing the challenge to this matter by discovering new equilibrium and accepting their new unity. What is closer to psychoanalysis is that not only Olga Tokarczuk, but her vision and her story, but the human substrate of her imagination, semantic and astral, sediment over countless seasons. It is the subject of terrestrial and anthropological and psychological studies: a physical and political, religious, symbolic world that takes on a complete center for its citizens and then all readers, and resurrects in the mythical and mythological dimension it cultivates. A voice that enlivens the writer's pages, but not as a collective oral history or as a growing written expression of his memory.

Tokarczuk randomly picks up a collection of essays, read one and then discard the whole thing. This can be read in any order, chronologically but still it fits together. Everyone loved Astronomy when we were child and spent lots of time in searching them. A Constellation seemed like a clear choice. Each article is a unit, they are autonomous entities in their own right, but they are part of a larger structure. Outside of writing, one piece says it is part of another. The fabric is residue at the end of a roll, a thing that is sharp and only part of another material. But on other side, the work is complete, it has its own path of life, a fair republic declares happily its independence. Tokarczuk's imagination, through research and writing skills revived Poland in the eighteenth century.

However, little things about people come and go, there are lots of little stories that remember us. The readers taken on a one-time travel adventure - as the novel selects four main representatives for each century that gives lots of experience. Since the twenty-first century, the devastated, anxious kuniki, his wife and son who vanished like a thin air. We wonder if kuniki was so upset that as we think he was, this arch has a certain element of suspense. Like the travel of heart of Chopin in the nineteenth century and the seventeenth century, we see the Dutch anatomist Philip cutting his own leg, a revolutionary invention and finally the most dangerous story from the eighteenth century, a slave born in Solomon-North Africa, then the Austrian nobleman - had his body stuffed and put on display made the book really fascinating.

The travel come to an end, "Each of my pilgrimages aims at some other pilgrims; today I finally arrived" (Flights, 404). After the careful examination of travel we can find every pilgrimage move into a deep silence, give us a clear way of our mysterious search of life. Once we studied about human body, soul, life and death - the constellation filled in the world of travel gives a valid point of destination. "One such person-body lay before us now, cut up into slices. And this gave us access to altogether unexpected points of view" (Flights, 407)

\section{REFERENCES}

[1] "Olga Tokarczuk: 'I Was Very Naive. I Thought Poland Would Be Able to Discuss the Dark Areas of Our History." $\quad$ Edited by Claire Armistead, Www.theguardian.com, Claire Armistead, 20 Apr. 2018, 07.00, www.theguardian.com/books/2018/apr/20/olgatokarczuk-interview-flights-man-booker-international.

[2] "Postmodernism: Literary Theory and Criticism ." Edited by Nasrullah Mambrol,

[3] N.ampproject.org,

2016 , literariness.org/2016/03/31/postmodernism/.

[4] Rojcewicz, Stephen. "Olga Tokarczuk: The Right Time and Place." Delos: A Journal of Translation and World Literature, vol. 35, no. 1, 2020, pp. 101-115., doi: $10.5744 /$ delos.2020.1009.

[5] "The Identity Crisis in the context of Globalization in the novel by OlgaTokarczuk's 'Flights"”

[6] Accents and Paradoxes of Modern Philology, no. 5, 2020, doi:10.26565/2521-6481-2020-5-1.

[7] "Flights by Olga Tokarczuk." Goodreads, Good reads, 14 Aug. 2018, www.goodreads.com/book/show/36885304flights.

[8] "Flights (Novel)." Wikipedia, Wikimedia Foundation, 8 Apr. 2021, en.wikipedia.org/wiki/Flights_(novel).

[9] Wood, James, and Ruth Franklin. "“Flights," a Novel That Never Settles Down." The New Yorker, www.newyorker.com/magazine/2018/10/01/flights-anovel-that-never-settles- down.

[10] The London Magazine, et al. "Review: Flights by Olga Tokarczuk." The London Magazine, 13 June 2018, www.thelondonmagazine.org/review-flights-olgatokarczuk/.

[11] "Flights - Olga Tokarczuk." Culture.pl, culture.pl/en/work/flights-olga-tokarczuk.

[12] "From Psychoanalysis to Literature: Olga Tokarczuk." European Journal of Psychoanalysis, www.journalpsychoanalysis.eu/from-psychoanalysis-to-literature-olgatokarczuk/.

[13] "Flights by Olga Tokarczuk." World Literature Today, 22 June 2018 , www.worldliteraturetoday.org/2018/july/flights-olgatokarczuk.

[14] Leah Greenblatt August 13, et al. "Why You Need to Read This Year's International Booker

[15] Prize Winner.” EW.com, ew.com/books/2018/08/13/flights-book-review/.

[16] Popova, Maria, editor. "Literary Constellation: Astronomy-Inspired Visualization of the 
[17] Opening Sentence of Beloved Book."

[18] Kozicka, Dorota. "Critical Constellations." Strategies of Literary Criticism for the Twentieth and Twenty-First Centuries, edited by Katarzyna Trzeciak, Charles David Legere, 2011, pp. 32-39.

[19] Pascarelli, Pietro. "From Psychoanalysis to Literature: Olga Tokarczuk.” European Journal of Psychoanalysis, www.journal-psychoanalysis.eu/from-psychoanalysis-toliterature-olga- tokarczuk/.

[20] Bahadur, Tulika. "Psychology, Physiology, Theology and Modern-Day Travel: 'Flights' by Olga Tokarczuk (Fitzcarraldo Editions)." On Art and Aesthetics, 28 Sept. 2020, onartandaesthetics.com/2018/09/01/psychologyphysiology-theology-and-modern-day-travel- flights-byolga-tokarczuk-fitzcarraldo-editions/.

[21] Franklin, Ruth. "Olga Tokarczuk's Novels Against Nationalism.” Google, Google, 29 July 2019, www.google.com/amp/s/www.newyorker.com/magazine/2 019/08/05/olga-tokarczuks- novels-againstnationalism/amp.

[22] Mazurczak, Filip. "The Reception of Olga Tokarczuk's Flights in the English Language Press." KONTEKSTY KULTURY, 2018.

[23] McAllister, Tom. "Review | 'Flights' Is a Beautifully Fragmented Look at Man's Longing for Permanence." The Washington Post, WP Company, 14 Aug. 2018, www.washingtonpost.com/entertainment/books/flights-isa-beautifully-fragmented-look-at- mans-longing-forpermanence/2018/08/13/9d685b94-85db-11e8-8553a3ce89036c78_story.html.

[24] Singh, Nandita, et al. "The Indian Connection of Nobel Winning Polish Author Olga Tokarczuk." ThePrint, 12 Oct. 2019, theprint.in/features/indian-connection-nobelwinning- polish-author-olga-tokarczuk/304554/. 